\title{
Marine macroalgal diversity assessment of Biri Island and Dalupirit Island, Northern Samar, Philippines
}

\author{
Susana F. Baldia ${ }^{1-3 *}$, Mark Timothy C. Kabiling ${ }^{1}$, Connie Anne L. Gabriel, \\ Angelique Nadine D.G. Abeleda ${ }^{1}$, Rose Celine A. Aguinaldo, \\ Ken Joseph E. Clemente, ${ }^{4}$ E Paciente A. Cordero Jr., \\ ${ }^{1}$ Department of Biological Sciences, College of Science; ${ }^{2}$ Research Center for the Natural \\ and Applied Sciences; ${ }^{3}$ Graduate School; ${ }^{4}$ Senior High School, \\ University of Santo Tomas, 1015 Manila, Philippines \\ ${ }^{5}$ Eastern Visayas State University \& Visayas State University, Leyte, Philippines
}

The Philippines with 7,641 islands is considered to have one of the most diverse aquatic ecosystem endowed with rich marine flora. This study focused on the assessment of macroalgae in the two islands of Northern Samar, Biri Island and Dalupirit Island, as well as their diversity, abundance and distribution. During collection on July 2016, the complete thalli of live specimens were gathered and their counts and distribution patterns were determined by using 15 quadrats in Dalupirit Island and 26 quadrats in Biri Island. A transect line length of $150 \mathrm{~m}$ and $260 \mathrm{~m}$ were used, respectively. About 86 macroalgal taxa were gathered and identified for both islands in which 22 out of the 86 taxa were found common to both islands. In Biri Island, 57 taxa were found with 35 being unique to the island. In Dalupirit Island, 51 taxa were identified with 29 being unique to the island. Rhodophyceae showed dominance both in Biri Island and Dalupirit Island having 46\% and 43\%, respectively, followed by Chlorophyceae with 33\% in Biri Island, and 39\% in Dalupirit Island, and lastly, Phaeophyceae having 19\% for Biri Island and 20\% for Dalupirit Island. In terms of percent cover, Phaeophyceae and Chlorophyceae are the most abundant in Biri Island and Dalupirit Island, respectively. Padina japonica is the most evenly distributed in Biri Island while Ulva reticulata is the most evenly distributed in Dalupirit Island.

Keywords: Biri Island, Chlorophyceae, Dalupirit Island, Macroalgae, Phaeophyceae, Rhodophyceae

\section{INTRODUCTION}

Situated at the apex of the coral triangle, the Philippines is known to be the richest marine eco-region in the world. With its 7,641 islands, the long coastline has provided a suitable

\footnotetext{
*To whom correspondence should be addressed:
} sfbaldia@yahoo.com habitat for seaweeds or macroalgae. Seaweeds contribute largely to marine production as evidenced by their presence in algal beds and reefs.

Seaweeds can also grow in shallow waters where they are found in estuaries and brackish waters thriving on substrates such as rocks, dead corals, pebbles, shells, and other plant materials. They 
contribute to the trophic structure in the coastal ecosystem where most marine animals feed and live on them.

In the Philippines, works on algae started in the 1960's when Filipino phycologists participated in algal research especially in the field of algal taxonomy. As early as the 1960s, studies on Philippine marine algae of the Hundred Islands were done by Meñez [1], followed by the significant contributions of Cordero [2] on the red algae, and Trono [3] on the marine benthic algae.

In the 1980s, notable works on macroalgae were contributed by Cordero [4]1980, Liao and Sotto [5] in Cebu, Marcos-Agngarayngay [6, 7] in Ilocos Norte, and Hurtado-Ponce et al. [8], in Panay Island. In the past decade, some interesting species included in the checklist of macroalgae from Southern Philippines were recorded by Geraldino et al. [9]. Following this was an updated names of taxa of the three major phyla of marine macroalgae from the Philippines by Ang et al. [10].

More recently, interest on utilization of macroalgae resulted to discovery of some bioactive substances present in the plant itself. Preliminary studies on phytochemical screening and antioxidant activity of some brown algae Sargassum species from Eastern Samar was conducted by Balanguit and Fuentes [11].

Among Philippines islands are Biri and Dalupirit, both lying in the east central periphery of the country, part of the Northern Samar in Eastern Visayas. At present, there has been no information available on the marine macroalgal flora of Biri Island and its adjacent islands. Therefore, it is the purpose of this research to contribute initial information on the marine macroalgal composition and distribution in the major islands of Northern Samar such as the Biri Island and Dalupirit Island. In addition, the study aims to determine the diversity, abundance, and dominance of macroalgae in both islands. This paper will add to the present available information on the distribution, species composition and diversity of macroalgal species in the Philippines.

\section{Methodology}

Study sites. The study sites are located along the coastal area of Northern Samar province (Fig. 1) 1241'18" N, 124'’22"49 E for Biri Island and $12^{\circ} 26^{\prime} 0^{\prime \prime} \mathrm{N}, 124^{\circ} 14^{\prime} 32^{\prime \prime}$ E for Dalupirit Island. The island of Dalupirit is a semi-exposed area because it is found within the internal waters of the Philippines. On the other hand, Biri Island is an exposed area located in the periphery of the Philippine archipelago facing directly to the Pacific Ocean. Dalupirit Island is characterized by its sandy beaches, while the natural habitat of Biri Island consists of naturally sculptured rock formations along the northern shore. The distance of the island of Biri and Dalupirit is approximately $32.1 \mathrm{~km}$.

Sampling procedures. Random quadrat and transect line were used in order to determine the algal counts and distribution patterns. During the collection conducted on July 2016, transect lines were laid in an area where there was a gradual transition between substrates. In Dalupirit Island, the transect line consisted of $150 \mathrm{~m}$ long plastic twine. On the other hand, $260 \mathrm{~m}$ long plastic twine was used for Biri Island. Both transect lines were marked at every $10 \mathrm{~m}$.

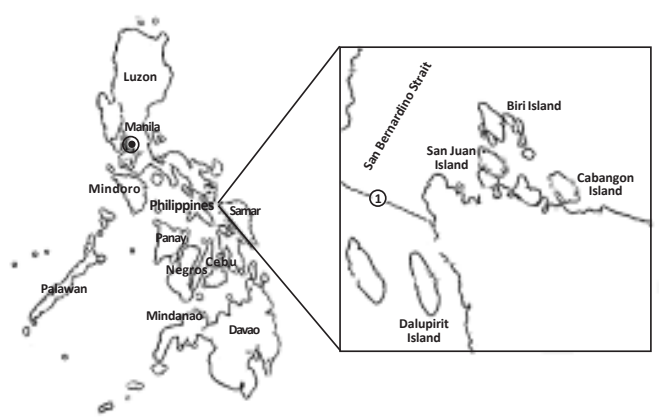

Figure 1. Map of Biri Island and Dalupirit Island, Northern Samar, Philippines 
The quadrats measured at $0.5 \times 0.5 \mathrm{~m}$ of polymerize vinyl chloride (PVC) pipes. The division for the regions of the quadrat was made via computer creating 25 regions within the quadrat. The sampling for the quadrats was done by randomly tossing the quadrat along the inner and outer sides of the transect lines every $10 \mathrm{~m}$.

Collection and preservation of specimens. Macroalgae were gathered by wading or snorkeling. The complete thalli of live specimens were collected by hand and/or by using a shovel. Quadrats and macroalgal specimens that were gathered were photographed using an underwater camera (GoPro). Specimens were then placed inside a zip lock containing 95\% salt water and $5 \%$ formaldehyde. The zip locks were then labeled with the quadrat number, specimen number and location. Afterwards, zip locks with specimens and water samples were then placed in a cooler box for preservation and protection from external temperature. The icebox was then transported to the laboratory for specimen cleaning, preservation, herbarium and identification.
In the UST Graduate School Laboratory, herbarium specimens were prepared initially by removing sediments from the specimens, letting the water flow through it and using a horse brush to remove smaller stones and debris attached to the specimens. Cleaned specimens were allowed to dry and were glued on to a Bristol board by using PVC glue. The different macroalgal genera were classified accordingly as red, green, or brown algae. Classification was based on Ganzon-Fortes [12] and Ang et al. [10] and identification by gross morphology and internal features following the works of Cordero $[2,4]$. Final verification of the specimens was done by Dr. Paciente A. Cordero Jr., a distinguished seaweed taxonomist in the Philippines.

\section{Results}

Macroalgal composition of Biri Island and Dalupirit Island. A total of 86 macroalgal taxa were identified for both sites. All collections represented the three classes of macroalgae (Table 1): Rhodophyceae (red algae), Chlorophyceae (green algae), and

Table 1. Checklist of the 86 macroalgal taxa in Biri Island and Dalupirit Island

\begin{tabular}{|c|c|c|}
\hline Genera & $\begin{array}{c}\text { Biri } \\
\text { Island }\end{array}$ & $\begin{array}{c}\text { Dalupirit } \\
\text { Island }\end{array}$ \\
\hline \multicolumn{3}{|l|}{ Chlorophyta (33) } \\
\hline Anadyomene plicata C. Agardh 1823 & $X$ & \\
\hline Avrainvillea lacerata Harvey ex J. Agardh 1887 & & $X$ \\
\hline Boergesenia forbesii (Harvey) Feldmann 1938 & $\mathrm{X}$ & $\mathrm{X}$ \\
\hline Boergesenia sp. & $\mathrm{X}$ & \\
\hline Boodlea composita (Harvey) F. Brand 1904 & $\mathrm{X}$ & \\
\hline Boodlea sp. & & $X$ \\
\hline Boodlea struveoides M. Howe 1918 & $\mathrm{X}$ & \\
\hline Caulerpa cupressoides (M. Vahl) C. Agardh 1817 & $\mathrm{X}$ & \\
\hline Caulerpa racemosa (ForsskaP) J. Agardh 1873 & $X$ & \\
\hline Caulerpa serrulata (Forsskal) J. Agardh 1837 & $\mathrm{X}$ & \\
\hline Caulerpa sertularioides (S. G. Gmelin) M.A. Howe 1905 & $X$ & \\
\hline Caulerpa taxifolia (M. Vahl) C. Agardh 1817 & $\mathrm{X}$ & \\
\hline Centroceras clavulatum (C. Agardh) Montagne 1846 & $\mathrm{X}$ & \\
\hline Centroceras sp. & $\mathrm{X}$ & \\
\hline Chaetoceros calcitrans (Paulsen) H.Takano 1968 & & $X$ \\
\hline Chaetomorpha crassa (C. Agardh) Kutzzing 1845 & & $\mathrm{X}$ \\
\hline Chaetomorpha sp. & $X$ & $\mathrm{X}$ \\
\hline Cladophora albida (Nees) Küzing 1843 & & $X$ \\
\hline
\end{tabular}


Table 1. (Continuation)

Cladophora sp.

\begin{tabular}{|c|c|c|}
\hline Cladophora sp. & & $\mathrm{X}$ \\
\hline Cladophoropsis gracillima E. Y. Dawson 1950 & $\mathrm{X}$ & \\
\hline Cladophoropsis sp. & & $\mathrm{X}$ \\
\hline Codium sp. & & $\mathrm{X}$ \\
\hline Enteromorpha chaetomorphoides Børgesen 1911 & & $\mathrm{X}$ \\
\hline Enteromorpha sp. & & $\mathrm{X}$ \\
\hline Halimeda macroloba Decaisne 1841 & $\mathrm{X}$ & $\mathrm{X}$ \\
\hline Halimeda opuntia (Linnaeus) J. V. Lamouroux 1816 & $\mathrm{X}$ & $\mathrm{X}$ \\
\hline Halimeda sp. & $\mathrm{X}$ & \\
\hline Ulva lactuca Linnaeus 1753 & & $\mathrm{X}$ \\
\hline Ulva pertusa Kjellman 1897 & & $\mathrm{X}$ \\
\hline Ulva reticulata ForsskaP 1775 & $\mathrm{X}$ & $\mathrm{X}$ \\
\hline Ulva sp. & & $\mathrm{X}$ \\
\hline Valonia fastigiata Harvey ex J. Agardh 1887 & $\mathrm{X}$ & \\
\hline Valonia ventricosa J. Agardh 1887 & & $\mathrm{X}$ \\
\hline \multicolumn{3}{|l|}{ Phaeophyta (14) } \\
\hline Dictyota cervicornis (Küzing) De Paula \& De Clerck 2006 & $\mathrm{X}$ & $\underline{X}$ \\
\hline Dictyota dichotoma (Hudson) J. V. & & $\mathrm{x}$ \\
\hline Hormophysa triquetra (C. Agardh) Kützing 1843 & $\mathrm{X}$ & $\mathrm{X}$ \\
\hline Padina australis Hauck 1887 & $\mathrm{X}$ & $\mathrm{X}$ \\
\hline Padina japonica Yamada 1931 & $\mathrm{X}$ & \\
\hline Padina minor Yamada 1925 & $\mathrm{x}$ & $\mathrm{X}$ \\
\hline Padina sp. & $\mathrm{X}$ & $\mathrm{X}$ \\
\hline Padina tetrastromatica Hauck 1887 & $\mathrm{X}$ & $\mathrm{X}$ \\
\hline Sargassum crassifolium J. Agardh 1848 & & $\mathrm{X}$ \\
\hline Sargassum currimaoense G. C. Trono 1994 & $\mathrm{X}$ & \\
\hline Sargassum hemiphyllum (Turner) C. Agardh 1820 & $\mathrm{X}$ & $x$ \\
\hline Sargassum piluliferum (Turner) C. Agardh 1820 & & $\mathrm{x}$ \\
\hline Sargassum polycystum C. Agardh 1824 & $\mathrm{x}$ & \\
\hline Sargassum sp. & $\mathrm{X}$ & \\
\hline \multicolumn{3}{|l|}{ Rhodophyta (39) } \\
\hline Acanthophora sp. & $\mathrm{X}$ & \\
\hline Acanthophora spicifera (M. Vahl) Børgesen 1910 & $\mathrm{x}$ & \\
\hline Amphiroa fragilissima (Linnaeus) J.V. Lamouroux 1816 & $\mathrm{X}$ & $\mathrm{X}$ \\
\hline Amphiroa sp. & $\mathrm{x}$ & \\
\hline Coelothrix irregularis (Harvey) Børgesen 1920 & $\mathrm{x}$ & $\mathrm{X}$ \\
\hline Corallina sp. & $\mathrm{x}$ & $\mathrm{x}$ \\
\hline Eucheuma sp. & $\mathrm{x}$ & \\
\hline Galaxaura falcata Kjellman 1900 & $\mathrm{X}$ & \\
\hline Galaxaura fastigiata Decaisne 1842 & $\mathrm{X}$ & \\
\hline Gelidiella acerosa (Forsskål) Feldmann \& Hamel 1934 & $\mathrm{x}$ & $\mathrm{X}$ \\
\hline Gelidiopsis intricata (C.Agardh) Vickers 1905 & $\mathrm{X}$ & \\
\hline Gelidiopsis repens (Kützing) Weber-van Bosse 1928 & & $x$ \\
\hline Gelidiopsis sp. & $\mathrm{X}$ & \\
\hline Gelidium sp. & & $\mathrm{X}$ \\
\hline Gracilaria bursa-pastoris (S. G. Gmelin) P. C.Silva 1952 & $\mathrm{X}$ & $\mathrm{X}$ \\
\hline Gracilaria confervoides (Linnaeus) Greville 1830 & & $x$ \\
\hline Gracilaria fastigiata J. Agardh 1852 & & $\mathrm{X}$ \\
\hline Gracilaria opuntia Durairatnam 1962 & $\mathrm{X}$ & \\
\hline Gracilaria salicornia (C. Agardh) E. Y. Dawson 1954 & $\mathrm{x}$ & \\
\hline Gracilaria sp. & $x$ & $\mathrm{X}$ \\
\hline
\end{tabular}


Table 1. (Continuation)

\begin{tabular}{|c|c|c|}
\hline Hypnea cervicornis J. Agardh 1851 & & $\mathrm{X}$ \\
\hline Hypnea charoides J. V. Lamouroux 1813 & & $\mathrm{X}$ \\
\hline Hypnea esperi Bory 1828 & & $\mathrm{X}$ \\
\hline Hypnea musciformis (Wulfen) J. V. Lamouroux 1813 & & $\mathrm{X}$ \\
\hline Hypnea seticulosa J. Agardh 1851 & $\mathrm{X}$ & $\mathrm{X}$ \\
\hline Hypnea sp. & $\mathrm{X}$ & $\mathrm{X}$ \\
\hline Hypnea valentiae (Turner) Montagne 1841 & $\mathrm{x}$ & \\
\hline Jania adhaerens J.V. Lamouroux 1816 & $\mathrm{X}$ & \\
\hline Jania sp. & $\mathrm{x}$ & \\
\hline Laurencia intermedia Yamada 1931 & $\mathrm{x}$ & $\mathrm{X}$ \\
\hline Laurencia obtusa (Hudson) J. V. Lamouroux 1813 & & $\mathrm{X}$ \\
\hline Laurencia papillosa (C. Agardh) Greville 1830 & & $\mathrm{X}$ \\
\hline Laurencia sp. & $\mathrm{X}$ & $\mathrm{X}$ \\
\hline Leveillea jungermannioides (Hering \& G. Martens Harvey 1855) & $\mathrm{x}$ & \\
\hline Mastophora rosea (C. Agardh) Setchell 1943 & & $\mathrm{X}$ \\
\hline Neurymenia fraxinifolia (Mertens ex Turner) J. Agardh 1863 & & $\mathrm{X}$ \\
\hline Peyssonnelia rubra (Greville) J. Agardh 1851 & $\mathrm{x}$ & \\
\hline Rhodymenia sp. & $\mathrm{x}$ & \\
\hline Spyridia sp. & $\mathrm{x}$ & \\
\hline
\end{tabular}

Phaeophyceae (brown algae). Out of 86 genera, 39 (46\%) belong to the Rhodophyceae, 33 (38\%) for Chlorophyceae and lastly, 14 (16\%) for Phaeophyceae. Of the 86 identified taxa, 62 were listed on the species rank and 24 on the genus rank.

From the total of 86 taxa, 22 were found common in both islands (Fig. 2). In Biri Island, 57 taxa were identified and only 35 were found unique. In Dalupirit Island, 51 taxa were identified although only 29 taxa were found unique.

In Biri Island, $46 \%$ belongs to Rhodophyceae, followed by Cholorophyceae with 33\% and lastly, Phaeophyceae having 19\%. In Dalupirit Island, 43\% belongs to Rhodophyceae, followed by Chlorophyceae with 39\%, and lastly, Phaeophyceae with 20\% (Fig. 2).

Distribution and abundance of macroalgae in Biri Island and Dalupirit Island. The substratum or rock empty spaces showed $27 \%$ cover in Biri Island. Phaeophyceae had the greatest percent cover with $36 \%$, followed by Chlorophyceae with $21 \%$ and the least is Rhodophyceae with 17\% (Fig. 3). In Dalupirit

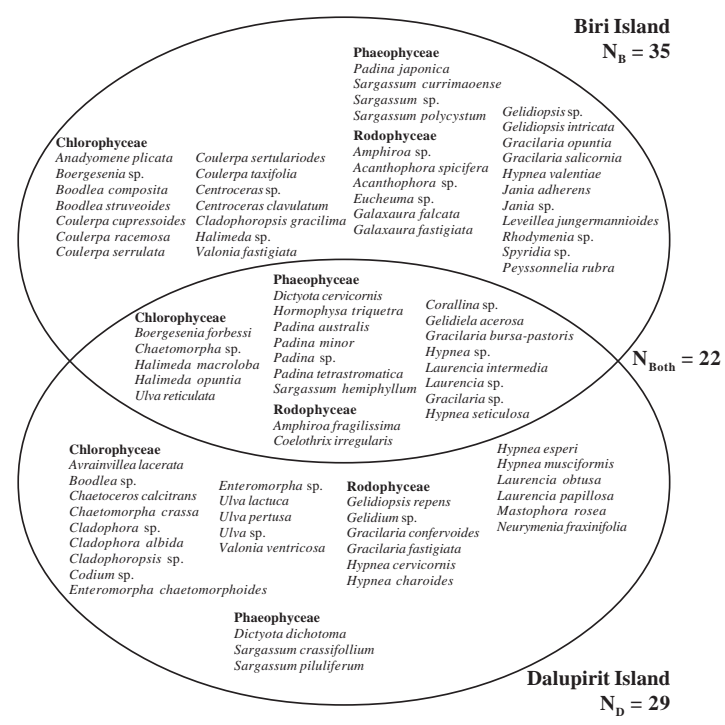

Figure 2. Venn diagram of macroalgal composition in Biri Island and Dalupirit Island

Island, seagrass dominated with $46 \%$ cover and the subratum or rock empty spaces with $10 \%$. Chlorophyceae had the greatest percent cover with $20 \%$, followed by Rhodophyceae with $16 \%$ and the least is Phaeophyceae with $9 \%$ cover (Fig. 3). 


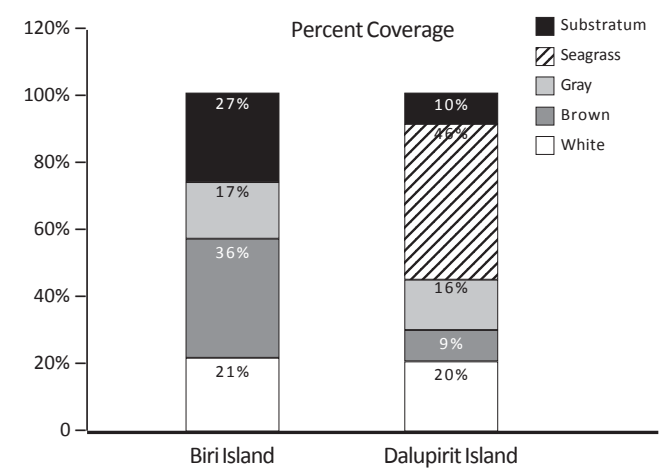

Figure 3. Percent cover in Biri Island and Dalupirit Island

In Fig. 4, most of the genera present in Biri Island are evenly distributed. On the other hand, most of the genera in Dalupirit Island are not evenly distributed.

Furthermore in Biri Island, Padina japonica is the most evenly distributed being present in 21 out of 26 quadrats. In Dalupirit Island, Ulva reticulata is the most evenly distributed being present in eight out of 15 quadrats (Fig. 4).

\section{Discussion}

In the Philippines, there are 543 published species of red algae, 197 species of green algae and 153 species of brown algae or a total of 893 species of macroalgae by Ang et al. [10]. In the present study, 86 taxa were identified with 62 species and 24 genera suggested as new records on the available literature of the marine flora and phytogeographic map in Northern Samar (Table $1)$.

Rhodophyceae showed the most number of species collected in both sites (Fig. 2). According to Lee [13], there are more Rhodophyceae in the world than all of the other major seaweed groups combined. Although marine red algae occur at all latitudes, there is a marked shift in their abundance from the equator to colder seas. There are few species in polar and subpolar while in temperate and tropical regions, the red algae predominates. This class have multicellular rhizoidal holdfast that serves as a strong attachment of thalli to substrates. In addition, Rhodophyceae have multiple life stages that help in their adaptation for survival. Their triphasic life cycle also explains why compared to brown and green algae, red algae are the most adaptable and morphologically diverse [14].

The lowest number of species collected in both sites belong to the class Phaeophyceae (Fig. 2). Since majority of the brown algae could be seen in the temperate region rather than the tropical region, it is expected to have low species diversity in the Philippines [14].

For marine algae, water motion affects almost every aspect of their ecology including their distribution and abundance across habitats of different wave pressure [15] as observed in Biri Island, and the distribution of gases and nutrients $[16,17]$. This will ultimately affect growth and their reproduction capacity [18], thus affecting their morphology [19, 20]. Water motion can also influence both static shape of an organism directly [19]. Macroalgae found in exposed intertidal zone (Biri Island) are tougher and shorter with narrower thalli, therefore they are more prone to wave motion compared to those growing in calmer areas [21] as exemplified by Dalupirit Island.

Brown algae species had the greatest cover in Biri Island (Fig. 3). Generally, brown algae exhibit larger biomasses than red algae due to their larger size [22]. Most brown algae species normally grow on bedrock, which is the substratum of Biri Island [23]. Brown algae in the intertidal zone exposed to wave action are usually tougher and shorter, with narrower thalli and are therefore more susceptible to action waves than those growing in calmer areas [21]. Among the brown algal species that were collected, one of the most prominent was from the genus Sargassum. Sargassum is widely distributed in the intertidal and shallow sub tidal 
rocky substrata of the tropical and subtropical coastal waters including the Philippines [24, 25]. Sargassum species are tough with its massive holdfast and can easily withstand wave motion. The presence of air bladders aid them float or stay upright, thus helping them to resist/tolerate strong wave motion.
The percent cover of green algae in Dalupirit Island is most abundant compared to red and brown algae (Fig. 3 ). This is due to fact that the water motion in Dalupirit Island is slow moving because of the islands protecting the site. For instance, the holdfast of the green alga like Halimeda is not strong enough compared to

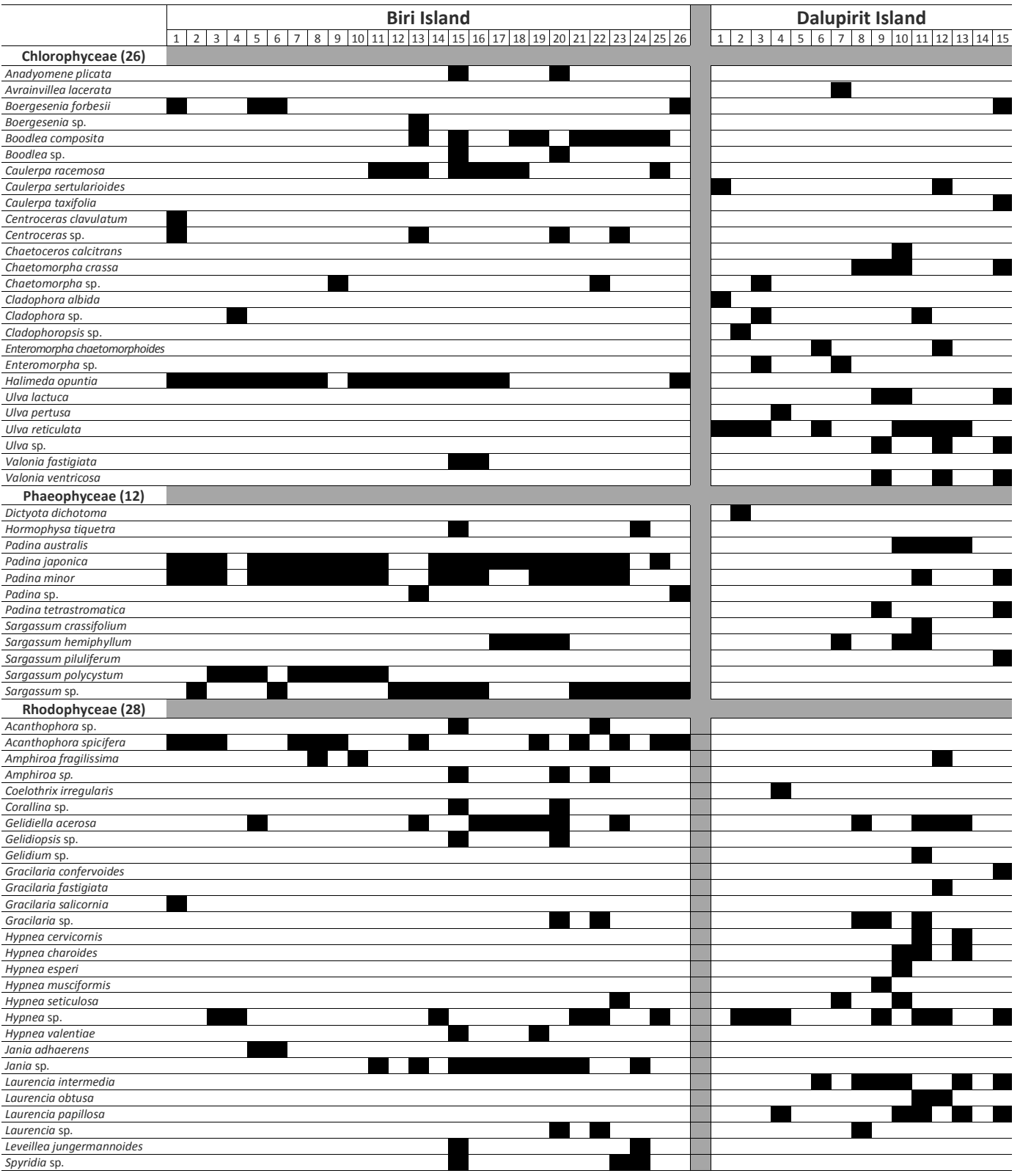

Figure 4. Presence and absence of genera per quadrat in Biri Island and Dalupirit Island 
other algae when it comes to fast moving water motion [14]. Seagrasses, also, have a huge percent cover in Dalupirit Island. One of the possible reasons for this is that they usually grow in sheltered coastal waters or bays, typified by Dalupirit Island due to its surrounding islands. Its short structure makes it capable of burrowing their roots in sandy or muddy areas complemented with good light. Generally, sheetlike and filamentous seaweeds, such as Ulva sp. and Cladophora sp., are dominant in unstable or polluted habitats [26-28].

In Biri Island, Phaeophyceae showed dominance than the other two classes (Fig.4). High dominance in species of Phaeophyceae means low diversity. Species of the marine brown algal genus Padina are widely distributed throughout the tropics [9]. Padina japonica belongs to Order Dictyotales and species that belong to this group are commonly found in warmer waters [14]. The lifecycle of Padina japonica is dominated by the sporophyte generation. The sporophyte dominance may be due to its greater resistance (longevity of individuals) to water movement that helps them establish their population [29]. This can be a possible reason for the evenness in the distribution of Padina japonica in Biri Island. Phaeophyceae showed dominance, but the distribution of the macroalgae in Biri Island is uneven.

Ulva reticulata is the most evenly distributed in Dalupirit Island (Fig. 4). It belongs to Class Ulvaceae, which are predominantly marine species. The growth of this species is not primarily influenced by water motion; rather it is influenced by lunar cycle [14]. The influence of lunar cycle in the growth of Ulva rather can be a possible reason why they are evenly distributed in Dalupirit Island. Ulva is also proliferated in many areas that receive anthropogenic nutrients [14]. Dalupirit Island consists of residential communities that contribute to anthropogenic nutrients, which makes it a suitable environment for Ulva reticulata. Also, a feature of nuisance growths of Ulva in enclosed and semi-enclosed waters as this compromises a large proportions of drift plants [14]. Since the species in Dalupirit Island did not show pronounced dominance, we could say that their distribution is even.

\section{Conclusion}

This paper easily provides a first account on the marine macroalgae in Biri Island and Dalupirit Island which reported a total of 86 taxa of which 62 were listed on the species rank and 24 on the genus rank. Collectively, the most number of species identified belongs to the Class Rhodophyceae, followed by Chlorophyceae and lastly, Phaeophyceae. By comparison of the percent cover, brown algae are the most abundant in Biri Island while green algae are the most abundant in Dalupirit Island. In terms of distribution, the macroalgae in Dalupirit Island showed evenness while in Biri Island, unevenness was exhibited due to some species dominance and possibly, temporally varied physico-chemical conditions. Thus, based on the above, Dalupirit Island is highly diverse than Biri Island.

\section{ACKNOWLEDGEMENTS}

The authors would like to acknowledge the Research Center for the Natural and Applied Sciences and the UST Graduate School for the space and other facilities extended to the researchers.

\section{REFERENCES}

[1] Meñez EG. The marine algae of the Hundred Islands, Philippines. Philippine Journal of Science 1961; 90:37-86.

[2] Cordero Jr PA. Studies on Philippines marine red algae. Special Publications from the Seto Marine Biological Laboratory Series 4, 1977.

[3] Trono Jr GC. Notes on some marine benthic algae in the Philippines. Kaliksan, Philippine Journal of Biology; 1972; 1:126-47.

[4] Cordero Jr PA. Taxonomy and Distribution of Philippine Useful Seaweeds. National Research Council of the Philippines Bulletin No. 81, 1980. 
[5] Liao LM, Sotto FB. A preliminary list of marine algae of Mactan Island and the neighboring islands. Philippine Scientist 1980; 17:94-100.

[6] Marcos-Agngarayngay ZD. Marine macro-algae of Ilocos Norte I. Cyanophyceae and Chlorophyceae. Ilocos Fish J 1983;1:59-103.

[7] Marcos-Agngarayngay, ZD. Marine macro-algae of Ilocos Norte II. Phaeophyta and Rhodophyta. Ilocos Fish J 1984; 1:1-66.

[8] Hurtado-Ponce AQ, Luhan MRJ, Guanzon NGJ. Seaweeds of Panay. (Tigbauan, Iloilo, Philippines: Aquaculture Department, Southeast Asian Fisheries Development Center, 1992.

[9] Geraldino PJL, Liao LM, Boo SM. Morphological study of the marine algal genus Padina (Dictyotales, Phaeophyceae) from Southern Philippines: 3 Species new to Philippines. Algae 2005; 20(2):99-112.

[10] Ang Jr PO, Leung S, Choi M. A verification of reports of marine algal species from the Philippines. Philippine Journal of Science 2013; 142:5-49.

[11] Balanquit BJ, Fuentes R. Preliminary phytochemical screening and antioxidant activity of some brown algae Sargassum species from Lawaan, Eastern Samar. Journal of Nature Studies 2015; 14(1):12-21.

[12] Ganzon-Fortes ET. A historical account of biodiversity studies on Philippine seaweeds (1800- 1999). Coastal Marine Science 2012; 35[13(1)]:182-201.

[13] Lee RE. Phycology. (UK: University Press, Cambridge, 1999).

[14] Lee RE. Phycology, $3^{\text {rd }}$ Edition. (UK: University Press, Cambridge, 2008).

[15] Denny MW. Biology and the Mechanics of the Wave-Swept Environment. (Princeton University Press, 1988).

[16] Patterson MR. A mass transfer explanation of metabolic scaling relations in some aquatic invertebrates and algae. Science 1992; 255(5050):1421-23.

DOI:10.1126/ science.255.5050.1421

[17] Sebens KP, Witting J, Helmuth B. Effects of water flow and branch spacing on particle capture by the reef coral Madracis mirabilis (Duchassaing and Michelotti). Journal of Experimental Marine Biology and Ecology 1997; 211(1):1-28. DOI:10.1016/s0022-0981(96)02636-6
[18] Parker HS. Influence of relative water motion on the growth, ammonium uptake and carbon and nitrogen composition of Ulva lactuca (Chlorophyta). Marine Biology 1981; 63(3):309_ 18. DOI:10.1007/bf00396001.

[19] Gerard VA, Mann KH. Growth and production of Laminaria longicruris (Phaeophyta) populations exposed to different intensities of water movement. Journal of Phycology 1979; 15(1):33-41.

[20] Blanchette CA. Size and Survival of Intertidal Plants in Response to Wave Action: A Case Study with Fucus gardneri. Ecology 1997; 78(5):1563. DOI:10.2307/2266149

[21] Hurtado AQ. Sargassum Studies in Currimao, Ilocos Norte, Northern Philippines I. Seasonal Variations in the Biomass of Sargassum carpophyllum J. Agardh, Sargassum ilicifolium (Turner) C. Agardh and Sargassum siliquosum J. Agardh (Phaeophyta, Sargassaceae). Southeast Asian Fisheries Development Center 1999. 42:321-25.

[22] Johnston CS. The ecological distribution and primary production of macrophytic marine algae in the eastern canaries. Hydrobiology 1969; 54(4):473-90.

[23] Hiscock S. A field key to the British brown seaweeds (Phaeophyta). AIDGAP 1979; 5:144.

[24] Tsuda RT. Morphological, zonational and seasonal studies of two species of Sargassum on the reefs of Guam. In: Proceeding of the $7^{\text {th }}$ International Seaweed Symposium, pp. 40-44. (Sapporo, Japan: University of Tokyo Press, 1972).

[25] Wreede RE. The phenology of three species of Sargassum (Sargassaceae, Phaeophyta) in Hawaii. Phycologia 1976; 15(2):175-83. DOI:10.2216/i0031-8884-15-2-175.1

[26] Littler MM, Littler DS. Relationships between macro algal functional form groups and substrata stability in a subtropical rocky-intertidal system. Journal of Experimental Marine Biology and Ecology 1984; 74(1):13-34. DOI:10.1016/00220981(84)90035-2

[27] Choi H, Lee K, Wan, XQ, Yoo H, Park H, Kim J, Chung I. Temporal variations in seaweed biomass in Korean coasts: Woejodo and Jusamdo, Jeonbuk. Algae 2008; 23(4):335-42. DOI:10.4490/algae.2008.23.4.335 
Baldia SF et al. | Acta Manilana 65 (2017)

[28] Kim J, Kang EJ, Edwards MS, Lee K, Jeong HJ, Kim KY. Species-specific responses of temperate macroalgae with different photosynthetic strategies to ocean acidification: a mesocosm study. Algae 2016; 31(3):243-56. DOI:10.4490/ algae.2016.31.8.20
[29] Allender BM. Effects of emersion and temperature upon growth of the tropical brown alga Padina japonica, using a tide-simulation apparatus. Marine Biology 1977; 40:95-100. 